\title{
Resistance of oral squamous cell carcinoma cells to cetuximab is associated with EGFR insensitivity and enhanced stem cell-like potency
}

\author{
YUICHI OHNISHI $^{1,2}$, YUKI MINAMINO ${ }^{1,2}$, KENJI KAKUDO $^{1}$ and MASAMI NOZAKI ${ }^{2}$ \\ ${ }^{1}$ Second Department of Oral and Maxillofacial Surgery, Osaka Dental University, Hirakata, Osaka 573-1121; \\ ${ }^{2}$ Department of Cell Biology, Research Institute for Microbial Diseases, Osaka University, Suita, Osaka 565-0871, Japan
}

Received April 8, 2014; Accepted May 13, 2014

DOI: $10.3892 /$ or.2014.3258

\begin{abstract}
Cetuximab, a specific anti-epidermal growth factor receptor (EGFR) monoclonal antibody, is used in cancer treatment. Although development of resistance to cetuximab is well recognized, the underlying mechanisms remain unclear. In the present study, we characterized cetuximab-resistant oral squamous cell carcinoma (OSCC) cell lines. The human OSCC cell lines HSC3, HSC4 and SAS were used in the present study. Effects of inhibitors including cetuximab on growth in cells were assessed by MTT assays. Southern blotting and immunofluorescence analysis were performed to examine protein expression and localization. Sphere formation was used to characterize stem cell-like properties. Floating aggregation culture was used for anchorage-independent growth. Cetuximab inhibited proliferation of HSC3 and HSC4 cells, but not SAS cells. Proliferation of all three cell lines was inhibited by the EGFR/ErbB2/ErbB4 inhibitor II. The EGFR inhibitor AG1478 strongly inhibited HSC3 and HSC4 proliferation, but that of SAS cells only moderately. EGFR proteins were localized on cell surface and phosphorylated in all three cell lines. SAS cells could proliferate in serum-free monolayer culture and formed spheres from single cells in floating culture. HSC 3 and HSC4 could not proliferate under serum-free culture conditions and could not form spheres. Growth of SAS spheres required serum, and was inhibited by both AG1478 and cetuximab. Thus, cetuximab-resistant SAS cells not only engaged in EGFR-independent growth but also exhibited stem cell-like properties. However, growth was EGFR-dependent in aggregation culture, and the SAS cell aggregates became cetuximab-sensitive. This suggests that cetuximab sensitivity is not only cell-type-dependent but is also affected by the growth microenvironment.
\end{abstract}

Correspondence to: Dr Masami Nozaki, Department of Cell Biology, Research Institute for Microbial Diseases, Osaka University, 3-1 Yamadaoka, Suita, Osaka 565-0871, Japan

E-mail: mnozaki@biken.osaka-u.ac.jp

Key words: cancer stem cells, cetuximab, epidermal growth factor receptor, oral squamous cell carcinoma, sphere formation

\section{Introduction}

The epidermal growth factor receptor [(EGFR)/ErbB1/HER1)] is a member of the ErbB tyrosine kinase family, which consists of ErbB1, ErbB2 (HER2), ErbB3 (HER3) and ErbB4 (HER4). All receptors of the ErbB family activate and regulate diverse cellular processes, including proliferation, survival, adhesion, migration and differentiation (1). Ligand binding potentiates receptor interaction with either a homologous molecule (homodimerization), a different ErbB-family receptor, or another cell surface tyrosine kinase receptor (IGF-1R or c-Met) (heterodimerization) (2-5). Dimer formation causes autophosphorylation of a tyrosine residue in the cytoplasmic domain and activates proteins triggering downstream events. Such proteins include MAPK, PI3K/AKT, phospholipase $\mathrm{C} \gamma$, PKC and STAT. Thus, EGFR proteins indirectly regulate gene expression. Variants of the genes encoding the EGFR family are oncogenes of various tumors. Upregulation of EGFR expression in many human epithelial cancers is associated with advanced tumor stage and an unfavorable prognosis $(6,7)$. Thus, EGFR is considered to be not only a useful prognostic biomarker but also a promising therapeutic target, and specific anti-EGFR monoclonal antibodies (mAbs) to extracellular domains of the proteins, and tyrosine kinase inhibitors (TKIs), have been developed and used in cancer treatment.

Cetuximab is a chimeric $\operatorname{IgG} 1$ monoclonal antibody that binds with high affinity to the extracellular domain of EGFR (8). The antibody blocks EGFR activation by preventing tyrosine kinase-mediated phosphorylation of the protein (9). In addition, antibody binding may trigger antibody-dependent cellular cytotoxicity (ADCC); the host immune system may attack cells covered with antibody bound to $\operatorname{EGFR}(10,11)$. Downstream effects of cetuximab include promotion of apoptosis, inhibition of cell cycle progression, tumor cell invasion and angiogenesis.

Cetuximab has been prescribed for patients with metastatic colorectal cancer (mCRC) (12-16) and head and neck squamous cell carcinoma (HNSCC) (17-21). Effects of monotherapy of cetuximab are shown in $13 \%$ of recurrent or metastatic HNSCC and improvement of overall survival benefits is shown in combination with radiation or other chemotherapy $(17,18)$. However, use of EGFR inhibitors containing cetuximab is 
associated with severe side-effects, a low reaction rate, and recurrence following treatments. These problems must be solved $(21,22)$. Thus, it is important to understand not only how cetuximab acts but also the mechanisms of cetuximab resistance. To date, various resistance mechanisms of cetuximab have been described. These fall into two categories. First, resistance may develop via constitutive activation of growth caused by changes in effectors of the EGFR signal transduction pathway (23-26). Second, proliferation may be stimulated by activation of receptors other than EGFR (27-30). However, the detailed features of cetuximab remain elusive.

Human cancer tissues are heterogeneous in nature and become differentiated during expansion of cancer stem cells (CSCs) (31). CSCs initiate tumorigenesis, and are involved in tumor recurrence and metastasis (32). Furthermore, data show that CSCs are highly resistant to anticancer drugs (33-35). Therefore, analysis of supposedly heterogenous tumor cell masses containing CSCs is required to identify the molecular mechanisms by which cetuximab resistance develops.

In the present study, we investigated the characteristics of cetuximab-resistant oral squamous cell carcinoma (OSCC) cells. We showed that cetuximab-resistant cells exhibited stem cell-like properties, and proliferation of such cells in monolayer culture was EGFR-independent. However, growth became EGFR-dependent in floatation culture, and cell spheres formed by cetuximab-resistant stem cell-like cells became cetuximab-sensitive. Thus, resistance to cetuximab is not only cell-type-dependent but is also influenced by the microenvironment in which cells grow.

\section{Materials and methods}

Cell culture and reagents. Three human OSCC cell lines, HSC3, HSC4 and SAS provided by the RIKEN BioResource Center (Ibaraki, Japan), were used in the present study. The cells were cultured in Dulbecco's modified Eagle's medium (DMEM) supplemented with $10 \%$ (v/v) fetal calf serum (FCS) (both from Life Technologies, Japan) at $37^{\circ} \mathrm{C}$ in a humidified atmosphere of $5 \%(\mathrm{v} / \mathrm{v}) \mathrm{CO}_{2}$ in air. Cetuximab (Erbitux $\left.{ }^{\circledR}\right)$ was purchased from Merck Serono (Tokyo, Japan). AG1478 and the EGFR/ErbB2/ErbB4 inhibitor II were from Calbiochem (Merck Millipore, Billerica, MA, USA). Antibodies used for western blot analyses and immunofluorescence were from the following sources; antibodies against EGFR and phosphorylated EGFR were obtained from Cell Signaling Technology (Denvers, MA, USA); the antibody against $\alpha$-tubulin was from Sigma-Aldrich (St. Louis, MO, USA); and that against Ki-67 from Dako (Tokyo, Japan).

Cell proliferation assay. Human OSCC cells (2x10³/well) were plated in 96 -well plates. After $24 \mathrm{~h}$ of growth, various reagents were added at the indicated concentrations and growth continued for a further 2, 4 or 6 days. All experiments were performed in triplicate. Cell proliferation was assessed using the CellTiter $96^{\circledR}$ Non-Radioactive Cell Proliferation Assay (Promega, Tokyo, Japan).

Aggregation culture and sphere formation. When aggregation culture was performed, $1 \times 10^{3}$ cells were seeded into each well of low adhesive 96-well plates (Sumitomo, Tokyo, Japan) and cultured in DMEM supplemented with $10 \%$ (v/v) FCS at $37^{\circ} \mathrm{C}$ under $5 \%(\mathrm{v} / \mathrm{v}) \mathrm{CO}_{2}$. To allow sphere formation, 1:1,000 dilution of a suspension of $1 \times 10^{3}$ cells was added to the well of low-adhesive 96-well U-shaped plates in 'sphere medium', which was DMEM/F12 supplemented with $2 \mathrm{mM}$ glutamine, $2 \%$ (v/v) B27, $20 \mathrm{ng} / \mathrm{ml}$ EGF, $20 \mathrm{ng} / \mathrm{ml} \mathrm{bFGF,} \mathrm{penicillin,} \mathrm{and}$ streptomycin.

Western blotting. OSCC cells were seeded in $60-\mathrm{mm}$ plates at a density of $2 \times 10^{5} /$ plate. After 2 days of growth, cells were collected and lysed in RIPA buffer [150 mM NaCl, $10 \mathrm{mM}$ Tris- $\mathrm{HCl}, \mathrm{pH} 8.0,1 \%$ (v/v) Nonidet P-40, 0.5\% (w/v) deoxycholic acid, $0.1 \%(\mathrm{w} / \mathrm{v}) \mathrm{SDS}$, and $5 \mathrm{mM}$ EDTA] containing $1 \mathrm{X}$ Halt $^{\mathrm{TM}}$ Protease Inhibitor Cocktail (Thermo Fisher Scientific, Yokohama, Japan). Samples were incubated at $95^{\circ} \mathrm{C}$ for $4 \mathrm{~min}$, separated by SDS-PAGE, and electrophoretically transferred to PVDF membranes (GE Healthcare, Tokyo, Japan). Non-specific binding was blocked by incubation in $5 \%(\mathrm{w} / \mathrm{v})$ bovine serum albumin (BSA) in TBS/Tween-20 (TBS-T) for $1 \mathrm{~h}$ at room temperature. Membranes were probed with antibodies against EGFR and phosphorylated EGFR in TBS-T overnight at $4^{\circ} \mathrm{C}$ and then incubated with HRP-conjugated goat anti-rabbit secondary antibody at a dilution of 1:5,000. Antibody-antigen complexes were detected by ECL plus western blotting detection reagent (GE Healthcare).

Immunofluorescence staining. Cultured cells and cell aggregates were fixed in $3.5 \%$ (w/v) formaldehyde, permeabilized in $0.2 \%(\mathrm{v} / \mathrm{v})$ Triton X-100, and blocked in $2 \%(\mathrm{w} / \mathrm{v})$ BSA. The primary antibodies were rabbit anti-EGFR, rabbit anti-phosphorylated EGFR, and mouse anti-Ki-67. Alexa Fluor 488-conjugated IgG (Life Technologies) was used as the secondary antibody. After incubation with the antibodies, SlowFade Gold Antifade reagent with 4',6-diamidino-2-phenylindole (DAPI; Invitrogen) was added. The specimens were observed using fluorescence microscopy.

\section{Results}

Cetuximab inhibits proliferation of AG1478-sensitive HSC3 and HSC4 cells, but not AG1478-resistant SAS cells. To compare the effect of cetuximab, EGFR inhibitor (AG1478), and ErbBs inhibitor (EGFR/ErbB2/ErbB4 inhibitor II) on OSCC cell lines, we first treated HSC3, HSC4 and SAS cells with increasing concentrations of the drugs for 6 days; proliferation was then assessed by MTT assay (Fig. 1A). Cetuximab at $1 \mu \mathrm{g} / \mathrm{ml}$ reduced the proliferation of HSC3 and HSC4 cells, but SAS cells proliferated to the extent of untreated cells even when the cetuximab concentration was $10 \mu \mathrm{g} / \mathrm{ml}$. Thus, HSC 3 and HSC4 cells were cetuximab-sensitive and SAS cells were cetuximab-resistant. Proliferation of HSC3 and HSC4 cells was effectively inhibited, in a concentration-dependent manner, by AG1478, and proliferation almost ceased when the inhibitor was added to 5 or $10 \mu \mathrm{M}$. AG1478 also reduced proliferation of SAS cells, but only at higher concentrations; SAS cell proliferation was not inhibited by AG1478 at $10 \mu \mathrm{M}$. Notably, EGFR/ErbB2/ErbB4 inhibitor II strongly inhibited proliferation of all three cell lines, killing most cells at 10 or $20 \mu \mathrm{M}$. These results suggested that HSC3 and HSC4 proliferation was regulated principally by EGFR, whereas SAS 

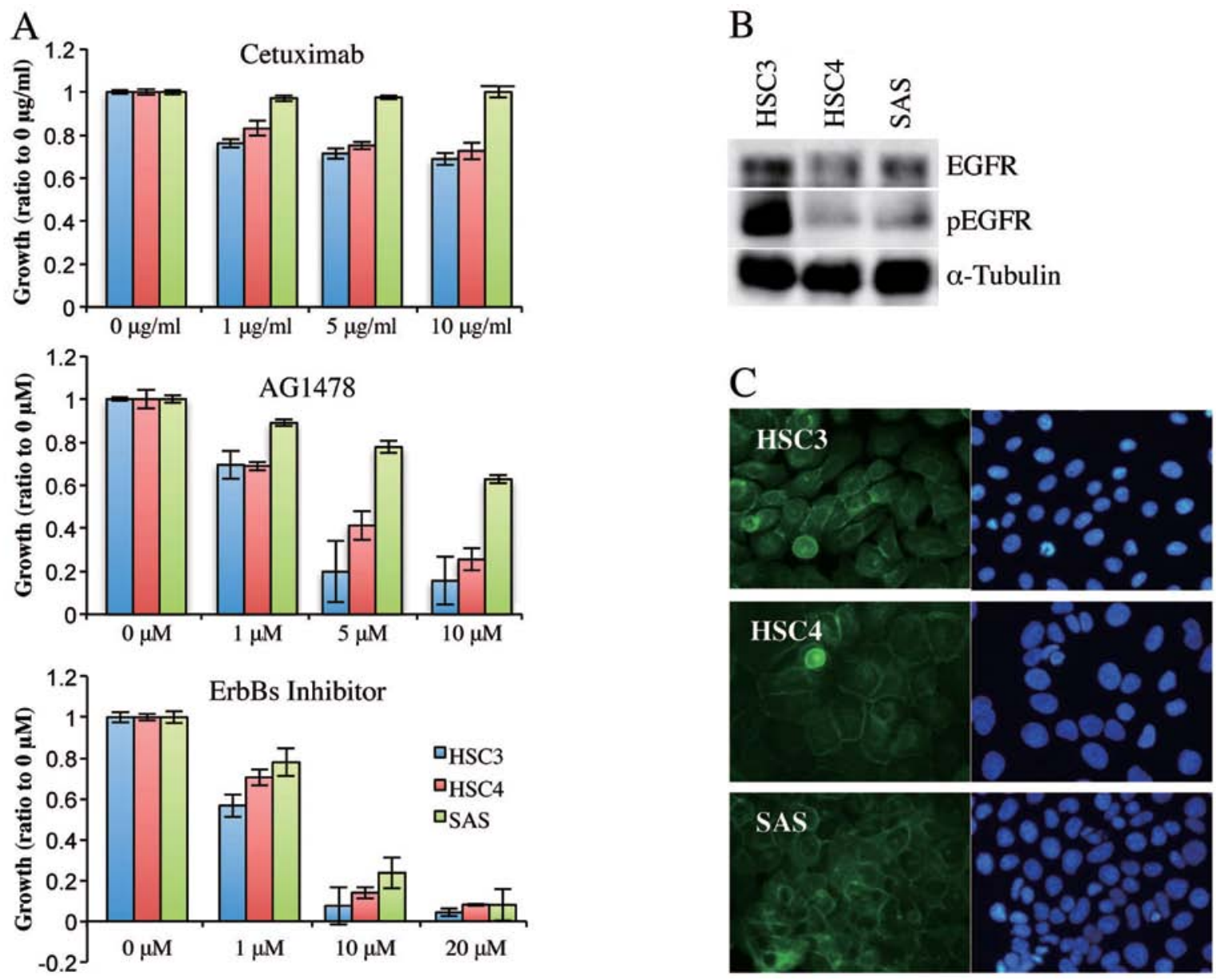

Figure 1. EGFR expression by cell lines and sensitivity of the cells to various inhibitors. (A) The effects of cetuximab, AG1478 and EGFR/ErbB2/ErbB4 inhibitor II on growth of HSC3, HSC4 and SAS cells, measured using the MTT assay. The values are means \pm SD of data from triplicate samples from one representative experiment. (B) Western blot analyses of expression of EGFR and phosphorylated EGFR in HSC3, HSC4 and SAS cell lines. $\alpha$-Tubulin served as an internal control. (C) Immunofluorescence analysis. HSC3, HSC4 and SAS cells were stained with an anti-EGFR antibody (left panels) or DAPI (right panels).

proliferation was controlled by a receptor of the ErbB-family other than EGFR.

We next analyzed expression and intracellular localization of EGFR in these cell lines. Western blotting using antibodies against EGFR and phosphorylated EGFR showed that EGFR protein was expressed and phosphorylated in all cell lines, although the phosphorylated EGFR level was higher in HSC3 cells than in the other two cell types (Fig. 1B). Immunofluorescence from anti-EGFR antibody was detected in the cell-cell contact regions of all cell lines, indicating that EGFR was located in the cell membrane (Fig. 1C). Thus, cetuximab-resistant SAS cells still expressed EGFR in the cell membrane and EGFR became phosphorylated when stimulated with a ligand.

Cetuximab-resistant OSCC cell lines proliferate autonomously in monolayer culture and form spheres in floating culture. To further characterize the cetuximab resistant OSCC cells, which are also AG1478 resistant, we compared the proliferative properties and sphere-formation capacities of the three cell lines. Fig. 2A shows that proliferation in monolayer culture was promoted by serum in a concentration-dependent manner. HSC3 and HSC4 cells proliferated only slightly over 6 and 4 days, respectively of serum-free culture. Notably, however, SAS cells proliferated strongly in serum-free medium over 4 days of culture.

We next analyzed the sphere formation capacity of single cells growing in serum-free sphere formation medium supplemented with bFGF and EGF (36). Suspensions of $1 \times 10^{3}$ cells were diluted so that U-shaped wells of low-adhesion 96-well plates received single cells in suspension, and the cells were cultured for 10 days. SAS cells formed spheres from single cells (Fig. 2B), and sphere diameter increased as culture time rose (Fig. 2B and C). In contrast, HSC4 cells did not form spheres from either single (Fig. 2B and C) or multiple cells (Fig. 2B). Thus, cetuximab-resistant SAS cells exhibited cancer stem cell-like characteristics but cetuximab-sensitive cells were incapable of forming growing aggregates.

Growth of SAS aggregates is regulated by EGFR and inhibited by cetuximab. HSC4 cells, similar to SAS cells, could form aggregates containing many cells, but unlike SAS aggregates, the HSC4 aggregates had poor growth characteristics. To compare the growth potential of OSCC cell lines under anchorage-independent culture conditions, $5 \times 10^{3}$ of the HSC3, HSC4 and SAS lines were seeded into U-shaped wells of lowadhesive 96-well plates and cultured in DMEM supplemented with $10 \%$ (v/v) FCS. Fig. 3A and B shows that all cell lines 
A
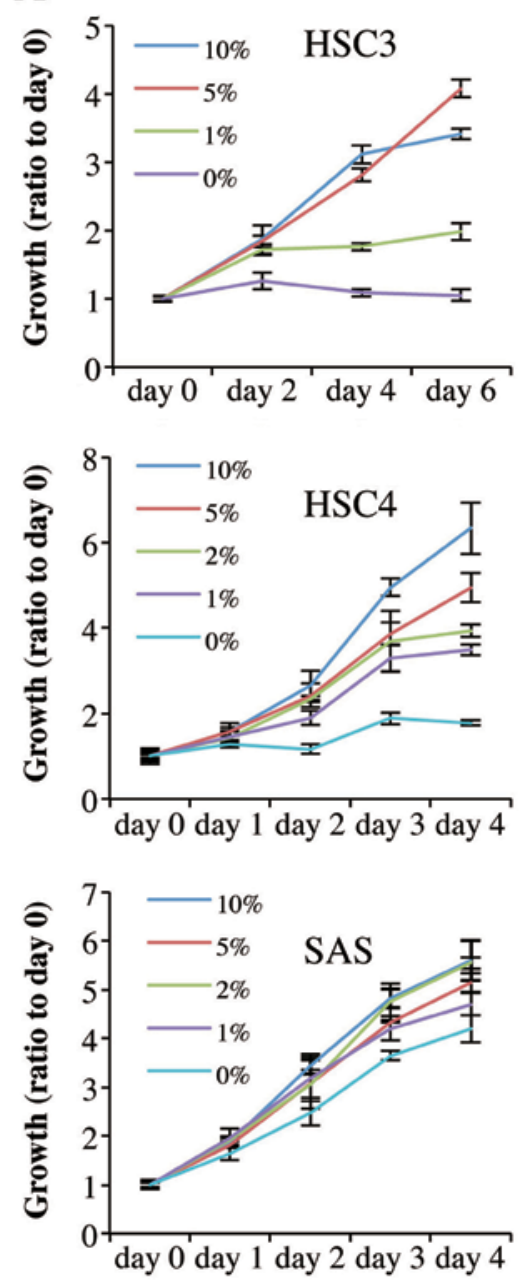

B

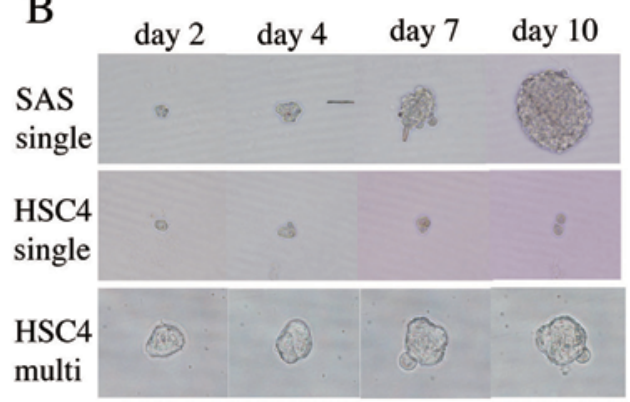

$\mathrm{C}$

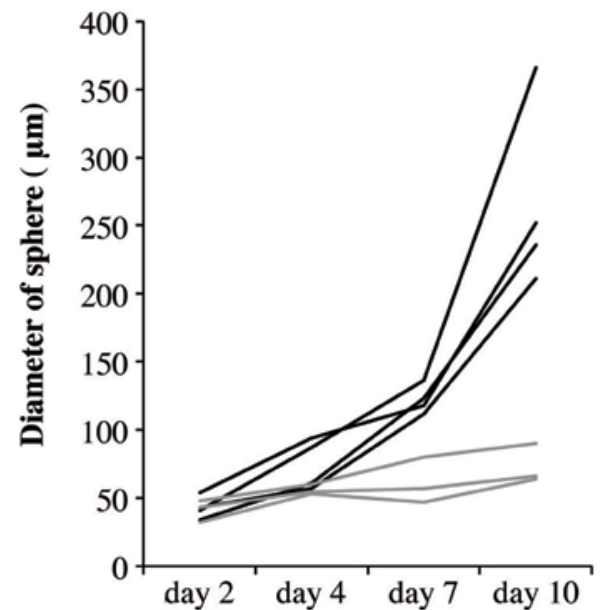

Figure 2. Serum-dependence of OSCC cell growth and sphere formation activity. (A) Serum dependence of OSCC cells. HSC3, HSC4 and SAS cells were cultured in DMEM with various concentrations of serum $(0,1,2,5$ or $10 \%$; all v/v) for $4-6$ days, and cells were enumerated using the MTT assay. The values are means \pm SD of data from triplicate samples from one representative experiment. (B) Phase-contrast micrographs of spheres cultured from single SAS cells and single or multiple HSC4 cells growing in low-adhesive 96-well culture plates. (C) Diameter of SAS (black lines) and HSC4 (gray lines) spheres after various culture durations.

A

2 day

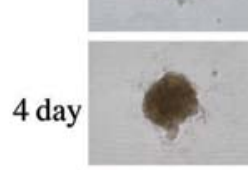

6 day

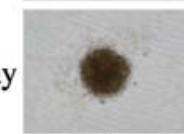

HSC3

B

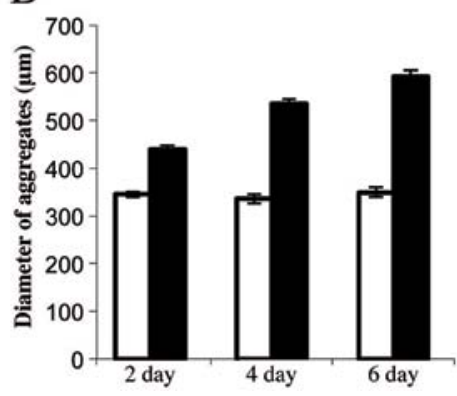

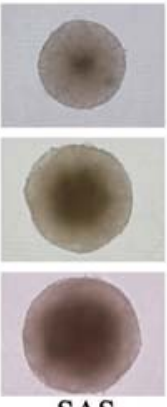

SAS
$\mathrm{C}$
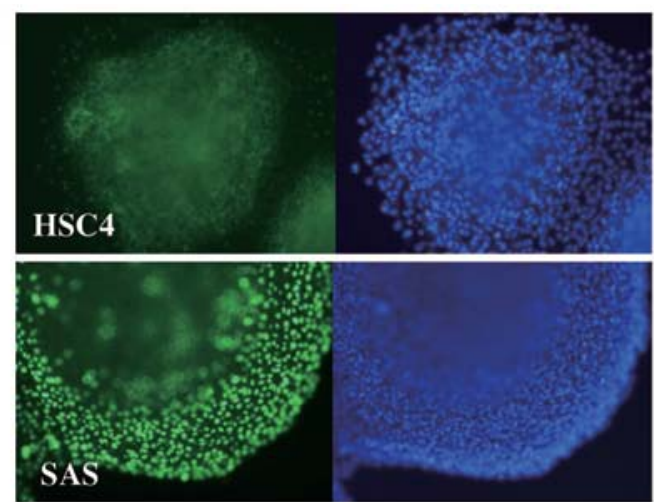

Figure 3. Aggregation culture of OSCC cell lines. (A) Phase-contrast photomicrographs of aggregates formed from $5 \times 10^{3} \mathrm{HSC} 3$, HSC4 and SAS cells growing in low-adhesive 96-well culture plates. (B) Diameters of SAS (black bars) and HSC4 (white bars) aggregates. The values are means \pm SD of the data from eight samples from one representative experiment. (C) Immunofluorescence analysis. HSC4 and SAS cell aggregates were stained with anti-Ki-67 (left panels) or DAPI (right panels). 
A
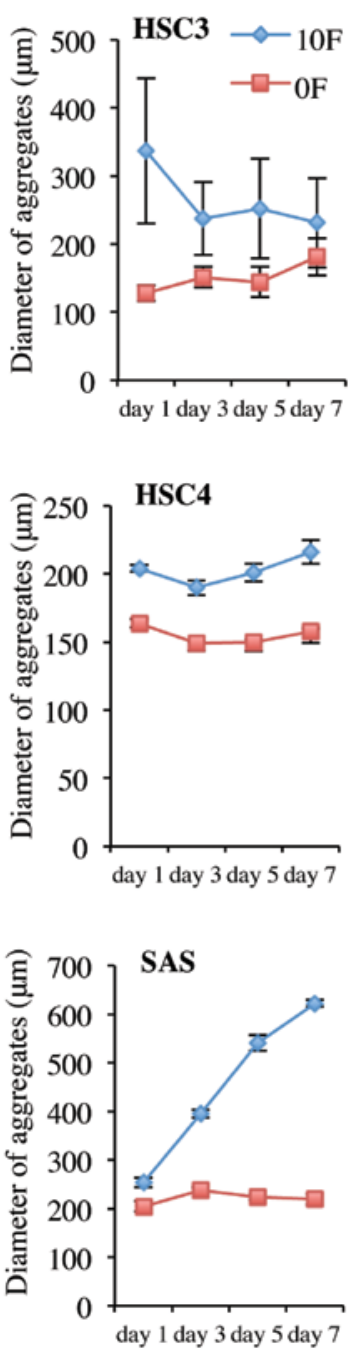

B

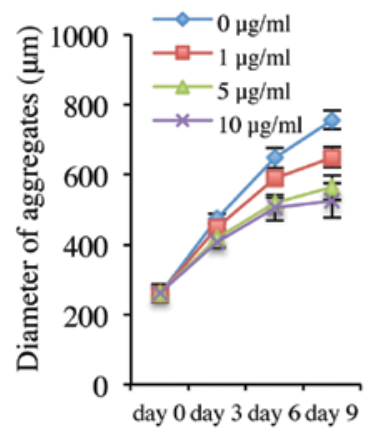

$\mathrm{C}$

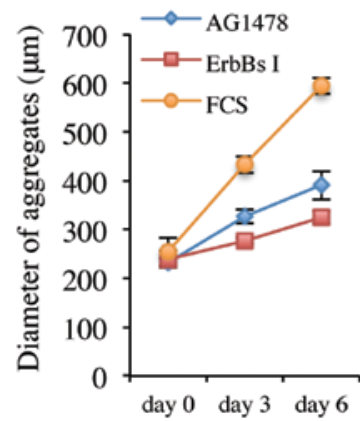

D

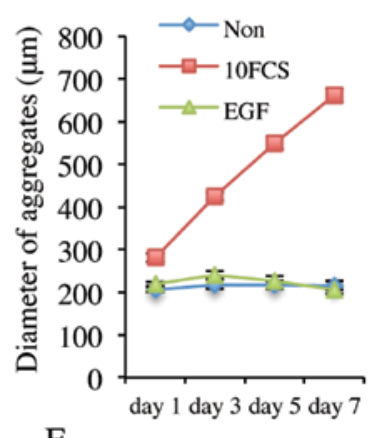

$\mathrm{E}$
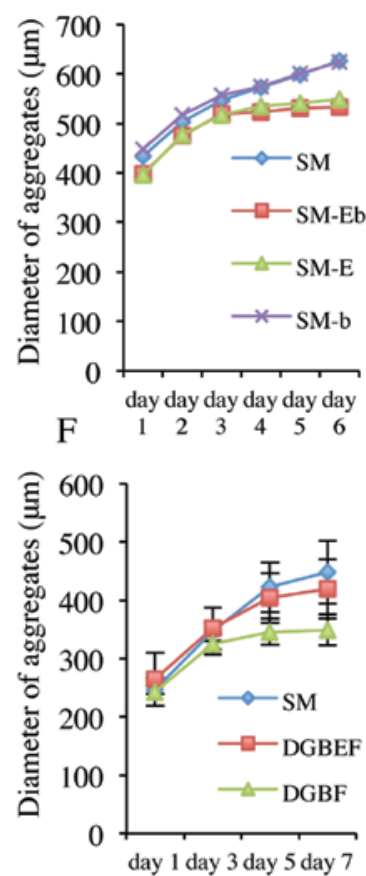

Figure 4. Effects of culture conditions on growth of OSCC cell aggregates. (A) The serum dependency of aggregate formation by, and growth of, HSC3, HSC4 and SAS cells. (B) Effects of cetuximab, and (C) AG1478 and the ErbBs inhibitor, on growth of SAS aggregates. (D) Effect of FCS on growth of SAS aggregates cultured in DMEM. (E) Effect of EGF on growth of SAS aggregates cultured in sphere medium. (F) Effect of medium composition on growth of SAS aggregates. Total of $5 \times 10^{3}$ cells were cultured in wells of low-adhesive 96 -well plates and aggregate diameters were measured. The values are means \pm SD of data from triplicate samples from one representative experiment.

formed aggregates on the first day of culture, but HSC3 and HSC4 aggregates were smaller than those formed by SAS cells and the diameters of the former aggregates did not increase thereafter. HSC4 aggregates were maintained for 6 days, but cell-cell contact was weak and dissociated cells became obvious in HSC3 aggregates. Conversely, the SAS aggregates increased in diameter as culture proceeded, and the aggregates were subjected to immunofluorescence staining using anti-Ki-67 antibody. Many nuclei of SAS aggregates stained with this antibody, but $\mathrm{Ki}$-67-positive nuclei were absent from HSC4 cell aggregates (Fig. 3C), indicating that SAS aggregation reflected proliferation of aggregated floating cells and that HSC4 could not proliferate in aggregation culture even in the presence of serum.

To determine whether growth of SAS aggregates was serum-independent, $5 \times 10^{3}$ cells were seeded into U-shaped well of low-adhesive 96-well plates in DMEM with or without $10 \%$ (v/v) FCS. As shown in Fig. 4A, all cell types formed aggregates in either serum-containing or -free medium. The
HSC3 and HSC4 aggregates formed in serum-containing medium were larger than those formed in serum-free medium, but SAS cell aggregates were of similar size in either medium, indicating that serum influenced the numbers of HSC 3 and HSC 4 cells that aggregated, but not the number of SAS cells. The diameter of SAS aggregates was greater in serum-containing medium, indicating that anchorageindependent growth of SAS cells was regulated by serum. Serum-dependent growth of SAS aggregates was reduced not only by an ErbBs inhibitor but also by cetuximab and AG1478 (Fig. 4B and C), indicating that activation of the EGFR signal transduction pathway may be associated with proliferation of SAS aggregates.

However, SAS aggregates did not proliferate when EGF was added to DMEM (Fig. 4D). On the other hand, when EGF was removed from sphere medium, proliferation of SAS aggregates ceased (Fig. 4E). Furthermore, although SAS aggregates proliferated in DMEM with added glutamine, B27, EGF and bFGF, removal of EGF caused proliferation to cease (Fig. 4F). 


\section{Discussion}

In the present study, we evaluated the proliferative behavior of oral SCC cell lines including cetuximab-sensitive HSC3 and HSC4 and cetuximab-resistant SAS. Notably, all cell lines expressed EGFR in the cell membrane and phosphorylated, regardless of cetuximab sensitivity status.

The monoclonal antibody cetuximab targets the extracellular domain of EGFR with high specificity and affinity (37). Cetuximab blocks ligand binding and thereby inhibits EGFR phosphorylation (9). Thus, cetuximab should inhibit EGFRdependent cell proliferation. In the present study, proliferation of HSC 3 and HSC4 cells was strongly associated with EGFR ligand-EGFR signaling, since proliferation was markedly reduced by the EGFR kinase inhibitor AG1478. Thus, cetuximab prevented EGFR phosphorylation, reducing proliferation of HSC3 and HSC4. These data are consistent with those of a previous report that EGFR biomarker analysis in non-small cell lung carcinoma patients showed that those with higher EGFR expression levels obtained more therapeutic benefit from cetuximab than did patients with lower EGFR levels (38). However, we found that SAS proliferation was not affected by cetuximab, although SAS cells expressed EGFR, which was localized in the cell membrane and phosphorylated, as did HSC 3 and HSC4 cells. A previous report showed that colorectal cancer patients with EGFR-negative tumors could nonetheless respond to cetuximab-based therapies (12). Collectively, the data suggest that EGFR status does not seem to have predictive value when used to gauge the efficacy of cetuximab treatment in oral cancer patients.

Although cetuximab is a valuable drug, both intrinsic resistance to the material and the development of acquired resistance, are well-recognized problems. Several mechanisms of resistance to cetuximab have been described. Western blot and immunofluorescence analysis showed that the expression level and localization of EGFR in SAS cells were similar to those of cetuximab-sensitive cell lines, indicating that neither the expression and activity level of EGFR (39), nor inappropriate cellular distribution of EGFR $(28,40)$ was probable cause of the drug resistance shown by SAS cells. However, the fact that phosphorylated EGFR is expressed by SAS cells suggests that EGFR is indeed stimulated by a ligand in such cells and plays a role in the regulation of a function other than growth, which may in turn be affected by cetuximab. Proliferation of SAS monolayer cultures was completely inhibited by EGFR/ErbB2/ErbB4 inhibitor II, but only moderately by AG1478, indicating that SAS proliferation was regulated principally by a receptor of the ErbB family other than EGFR. SAS cells also actively proliferated in serum-free culture. Such autonomous growth of SAS cells was strongly inhibited by EGFR/ErbB2/ErbB4 inhibitor II and moderately suppressed by AG1478 (data not shown), as was also true of growth in serum-containing culture. These results suggest that SAS cells express a high level of ErbB ligands, binding to ErbB receptors other than EGFR, thus explaining the cetuximab resistance of such cells. It was previously reported that HB-EGF played an important role in the development of cetuximab resistance in HNSCC (41).

Sphere formation revealed the stem cell-like properties of SAS cells. HSC3 and HSC4 cells essentially lacked such properties, being unable to form spheres from single cells. This suggests that expression of stem cell-like features is associated with cetuximab resistance under anchorage-dependent growth conditions. Spheres were grown in sphere medium supplemented with bFGF and EGF, but not if EGF was absent. SAS aggregates grew in DMEM supplemented with $10 \%$ (v/v) FCS but HSC 3 and HSC4 aggregates did not, although cells of all three tested lines formed aggregates. SAS aggregates did not grow in serum-free DMEM, rather requiring serum components including EGF. Aggregated growth was inhibited by cetuximab and AG1478. Thus, SAS cells lost the ability to proliferate autonomously in anchorage-independent aggregation culture; such growth was rather controlled by the EGFR pathway. It thus appears that the cetuximab sensitivity status of stem cell-like cancer cells is affected by the cellular microenvironment.

In summary, cetuximab resistant OSCC cells not only engaged in EGFR-independent growth in monolayer culture but also exhibited stem cell-like properties. However, growth was EGFR-dependent in aggregation culture of the cell, and the cell aggregate became cetuximab-sensitive. We found that cetuximab sensitivity is not only cell-type-dependent but is also affected by the growth microenvironment.

\section{Acknowledgements}

This study was supported by funding from the Osaka University and Osaka Dental University.

\section{References}

1. Yarden Y and Sliwkowski MX: Untangling the ErbB signalling network. Nat Rev Mol Cell Biol 2: 127-137, 2001.

2. Harris RC, Chung E and Coffey RJ: EGF receptor ligands. Exp Cell Res 284: 2-13, 2003.

3. Arteaga CL and Baselga J: Tyrosine kinase inhibitors: why does the current process of clinical development not apply to them? Cancer Cell 5: 525-531, 2004.

4. Galer CE, Corey CL, Wang Z, Younes MN, Gomez-Rivera F, Jasser SA, Ludwig DL, El-Naggar AK, Weber RS and Myers JN: Dual inhibition of epidermal growth factor receptor and insulinlike growth factor receptor I: reduction of angiogenesis and tumor growth in cutaneous squamous cell carcinoma. Head Neck 33: 189-198, 2011.

5. Engelman JA, Zejnullahu K, Mitsudomi T, Song Y, Hyland C, Park JO, Lindeman N, Gale CM, Zhao X, Christensen J, Kosaka T, Holmes AJ, Rogers AM, Cappuzzo F, Mok T, Lee C, Johnson BE, Cantley LC and Jänne PA: MET amplification leads to gefitinib resistance in lung cancer by activating ERBB3 signaling. Science 316: 1039-1043, 2007.

6. Ang KK, Berkey BA, Tu X, Zhang HZ, Katz R, Hammond EH, Fu KK and Milas L: Impact of epidermal growth factor receptor expression on survival and pattern of relapse in patients with advanced head and neck carcinoma. Cancer Res 62: 7350-7356, 2002.

7. Chung CH, Zhang Q, Hammond EM, Trotti AM III, Wang H, Spencer S, Zhang HZ, Cooper J, Jordan R, Rotman MH and Ang KK: Integrating epidermal growth factor receptor assay with clinical parameters improves risk classification for relapse and survival in head-and-neck squamous cell carcinoma. Int J Radiat Oncol Biol Phys 81: 331-338, 2011.

8. Galizia G, Lieto E, De Vita F, Orditura M, Castellano P, Troiani T, Imperatore V and Ciardiello F: Cetuximab, a chimeric human mouse anti-epidermal growth factor receptor monoclonal antibody, in the treatment of human colorectal cancer. Oncogene 26: 3654-3660, 2007.

9. Li S, Schmitz KR, Jeffrey PD, Wiltzius JJ, Kussie P and Ferguson KM: Structural basis for inhibition of the epidermal growth factor receptor by cetuximab. Cancer Cell 7: 301-311, 2005. 
10. López-Albaitero A and Ferris RL: Immune activation by epidermal growth factor receptor-specific monoclonal antibody therapy for head and neck cancer. Arch Otolaryngol Head Neck Surg 133: 1277-1281, 2007.

11. Kurai J, Chikumi H, Hashimoto K, Yamaguchi K, Yamasaki A, Sako T, Touge H, Makino H, Takata M, Miyata M, Nakamoto M, Burioka N and Shimizu E: Antibody-dependent cellular cytotoxicity mediated by cetuximab against lung cancer cell lines. Clin Cancer Res 13: 1552-1561, 2007.

12. Chung KY, Shia J, Kemeny NE, Shah M, Schwartz GK, Tse A, Hamilton A, Pan D, Schrag D, Schwartz L, Klimstra DS, Fridman D, Kelsen DP and Saltz LB: Cetuximab shows activity in colorectal cancer patients with tumors that do not express the epidermal growth factor receptor by immunohistochemistry. J Clin Oncol 23: 1803-1810, 2005.

13. Jonker DJ, O'Callaghan CJ, Karapetis CS, Zalcberg JR, Tu D, Au HJ, Berry SR, Krahn M, Price T, Simes RJ, Tebbutt NC, van Hazel G, Wierzbicki R, Langer C and Moore MJ: Cetuximab for the treatment of colorectal cancer. N Engl J Med 357: 2040-2048, 2007.

14. Sobrero AF, Maurel J, Fehrenbacher L, Scheithauer W, Abubakr YA, Lutz MP, Vega-Villegas ME, Eng C, Steinhauer EU, Prausova J, Lenz HJ, Borg C, Middleton G, Kröning H, Luppi G Kisker O, Zubel A, Langer C, Kopit J and Burris HA III: EPIC: phase III trial of cetuximab plus irinotecan after fluoropyrimidine and oxaliplatin failure in patients with metastatic colorectal cancer. J Clin Oncol 26: 2311-2319, 2008.

15. Bokemeyer C, Bondarenko I, Makhson A, Hartmann JT, Aparicio J, de Braud F, Donea S, Ludwig H, Schuch G, Stroh C, Loos AH, Zubel A and Koralewski P: Fluorouracil, leucovorin and oxaliplatin with and without cetuximab in the first-line treatment of metastatic colorectal cancer. J Clin Oncol 27: 663-671, 2009.

16. Van Cutsem E, Köhne CH, Hitre E, Zaluski J, Chang Chien CR, Makhson A, D'Heans G, Pintér T, Lim R, Bodoky G, Roh JK, Folprecht G, Ruff P, Stroh C, Tejpar S, Schlichting M, Nippgen J and Rougier P: Cetuximab and chemotherapy as initial treatment for metastatic colorectal cancer. N Engl J Med 360: 1408-1417, 2009.

17. Vermorken JB, Mesia R, Rivera F, Remenar E, Kawecki A, Rottey S, Erfan J, Zabolotnyy D, Kienzer HR, Cupissol D, Peyrade F, Benasso M, Vynnychenko I, De Raucourt D, Bokemeyer C, Schueler A, Amellal N and Hitt R: Platinum-based chemotherapy plus cetuximab in head and neck cancer. N Engl J Med 359: 1116-1127, 2008.

18. Bonner JA, Harari PM, Giralt J, Azarnia N, Shin DM, Cohen RB, Jones CU, Sur R, Raben D, Jassem J, Ove R, Kies MS, Baselga J, Youssoufian H, Amellal N, Rowinsky EK and Ang KK: Radiotherapy plus cetuximab for squamous-cell carcinoma of the head and neck. N Engl J Med 354: 567-578, 2006.

19. Herbst RS, Arquette M, Shin DM, Dicke K, Vokes EE, Azarnia N, Hong WK and Kies MS: Phase II multicenter study of the epidermal growth factor receptor antibody cetuximab and cisplatin for recurrent and refractory squamous cell carcinoma of the head and neck. J Clin Oncol 23: 5578-5587, 2005.

20. Baselga J, Trigo JM, Bourhis J, Tortochaux J, Cortés-Funes H, Hitt R, Gascón P, Amellal N, Harstrick A and Eckardt A: Phase II multicenter study of the antiepidermal growth factor receptor monoclonal antibody cetuximab in combination with platinum-based chemotherapy in patients with platinum-refractory metastatic and/or recurrent squamous cell carcinoma of the head and neck. J Clin Oncol 23: 5568-5577, 2005.

21. Burtness B, Goldwasser MA, Flood W, Mattar B, Forastiere AA Eastern Cooperative Oncology Group: Phase III randomized trial of cisplatin plus placebo compared with cisplatin plus cetuximab in metastatic/recurrent head and neck cancer: an Eastern Cooperative Oncology Group study. J Clin Oncol 23: 8646-8654, 2005

22. Tejani MA, Cohen RB and Mehra T: The contribution of cetuximab in the treatment of recurrent and/or metastatic head and neck cancer. Biologics 4: 173-185, 2010.

23. Sok JC, Coppelli FM, Thomas SM, Lange MN, Xi S, Hunt JL, Freilino ML, Graner NW, Wikstrand CJ, Bigner DD, Gooding WE, Furnari FB and Grandis JR: Mutant epidermal growth factor receptor (EGFRvIII) contributes to head and neck cancer growth and resistance to EGFR targeting. Clin Cancer Res 12: 5064-5073, 2006.

24. Chen LF, Cohen EE and Grandis JR: New strategies in head and neck cancer: understanding resistance to epidermal growth factor receptor inhibitors. Clin Cancer Res 16: 2489-2495, 2010 .
25. Kim SM, Kim JS, Kim JH, Yun CO, Kim EM, Kim HK, Solca F, Choi SY and Cho BC: Acquired resistance to cetuximab is mediated by increased PTEN instability and leads cross-resistance to gefitinib in HCC827 NSCLC cells. Cancer Lett 296: 150-159, 2010.

26. Dunn EF, Iida M, Myers RA, Campbell DA, Hintz KA, Armstrong EA, Li C and Wheeler DL: Dasatinib sensitizes KRAS mutant colorectal tumors to cetuximab. Oncogene 30: 561-574, 2011.

27. Ciardiello F, Bianco R, Caputo R, Caputo R, Damiano V, Troiani T, Melisi D, De Vita F, De Placido S, Bianco AR and Tortora G: Antitumor activity of ZD6474, a vascular endothelial growth factor receptor tyrosine kinase inhibitor, in human cancer cells with acquired resistance to antiepidermal growth factor receptor therapy. Clin Cancer Res 10: 784-793, 2004.

28. Wheeler DL, Iida M, Kruser TJ, Nechrebecki MM, Dunn EF, Armstrong EA, Huang S and Harari PM: Epidermal growth factor receptor cooperates with Src family kinases in acquired resistance to cetuximab. Cancer Biol Ther 8: 696-703, 2009.

29. Brand TM, Iida M and Wheeler DL: Molecular mechanisms of resistance to the EGFR monoclonal antibody cetuximab. Cancer Biol Ther 11: 777-792, 2011.

30. Yonesaka K1, Zejnullahu K, Okamoto I, Satoh T, Cappuzzo F, Souglakos J,Ercan D, Rogers A, Roncalli M, Takeda M, Fujisaka Y, Philips J, Shimizu T, Maenishi O, Cho Y, Sun J, Destro A, Taira K, Takeda K, Okabe T, Swanson J, Itoh H, Takada M, Lifshits E, Okuno K, Engelman JA, Shivdasani RA, Nishio K, Fukuoka M, Varella-Garcia M, Nakagawa K and Jänne PA: Activation of ERBB2 signaling causes resistance to the EGFR-directed therapeutic antibody cetuximab. Sci Transl Med 3: 99ra86, 2011.

31. Al-Hajj M, Wicha MS, Benito-Hernandez A, Morrison SJ and Clarke MF: Prospective identification of tumorigenic breast cancer cells. Proc Natl Acad Sci USA 100: 3983-3988, 2003.

32. Clarke MF, Dick JE, Dirks PB, Eaves CJ, Jamieson CH, Jones DL, Visvader J, Weissman IL and Wahl GM: Cancer stem cells - perspectives on current status and future directions: AACR workshop on cancer stem cells. Cancer Res 66: 9339-9344, 2006.

33. Todaro M, Alea MP, Di Stefano AB, Cammareri P, Vermeulen L, Iovino F, Tripodo C, Russo A, Gulotta G, Medema JP and Stassi G: Colon cancer stem cells dictate tumor growth and resist cell death by production of interleukin-4. Cell Stem Cell 1: 389-402, 2007.

34. Ma S, Lee TK, Zheng BJ, Chan KW and Guan XY: CD133 ${ }^{+} \mathrm{HCC}$ cancer stem cells confer chemoresistance by preferential expression of the Akt/PKB survival pathway. Oncogene 27: 1749-1758, 2008.

35. Salmaggi A, Boiardi Ak, Gelati M, Russo A, Calatozzolo C, Ciusani E, Sciacca FL, Ottolina A, Parati EA, La Porta C, Alessandri G, Marras C, Croci D and De Rossi M: Glioblastomaderived tumorospheres identify a population of tumor stem-like cells with angiogenic potential and enhanced multidrug resistance phenotype. Glia 54: 850-860, 2006.

36. Dontu G, Abdallah WM, Foley JM, Jackson KW, Clarke MF, Kawamura MJ and Wicha MS: In vitro propagation and transcriptional profiling of human mammary stem/progenitor cells. Genes Dev 17: 1253-1270, 2003.

37. Thomas SM and Grandis JR: Pharmacokinetic and pharmacodynamics properties of EGFR inhibitors under clinical investigation. Cancer Treat Rev 30: 255-268, 2004.

38. Pirker R, Pereira JR, von Pawel J, Krzakowski M, Ramlau R, Park K, de Marinis F, Eberhardt WE, Paz-Ares L, Störkel S, Shumacher KM, von Heydebreck A, Celik I and O'Byrne KJ: EGFR expression as a predictor of survival for first-line chemotherapy plus cetuximab in patients with advanced non-small-cell lung cancer: analysis of data from the phase 3 FLEX study. Lancet Oncol 13: 33-42, 2012.

39. Wheeler DL, Huang S, Kruser TJ, Nechrebecki MM, Armstrong EA, Benavente S, Gondi V, Hsu KT and Harari PM: Mechanisms of acquired resistance to cetuximab: role of HER (ErbB) family members. Oncogene 27: 3944-3956, 2008.

40. Nevo J, Mattila E, Pellinen T, Yamamoto DL, Sara H, Iljin K, Kallioniemi O, Bono P, Heikkilä P, Joensuu H, Wärri A and Ivaska J: Mammary-derived growth inhibitor alters traffic of EGFR and induces a novel form of cetuximab resistance. Clin Cancer Res 15: 6570-6581, 2009.

41. Hatakeyama H, Cheng H, Wirth P, Counsell A, Marcrom SR, Wood CB, Pohlmann PR, Gilbert J, Murphy B, Yarbrough WG, Wheeler DL, Harari PM, Guo Y, Shyr Y, Slebos RJ and Chung CH: Regulation of heparin-binding EGF-like growth factor by miR-212 and acquired cetuximab-resistance in head and neck squamous cell carcinoma. PLoS One 5: e12702, 2010. 